\title{
Anti-aging role of Chinese herbel medicine: an overview of scientific evidence from 2008 to 2018
}

\author{
Junnan Zhao ${ }^{1}, \mathrm{Xu} \mathrm{Lan}{ }^{1}$, Yue Liu ${ }^{2}$, Yanfei Liu ${ }^{3}$, Yanfang Xian ${ }^{4}$, Zhixiu Lin ${ }^{4}$, Fengqin Xu ${ }^{1}$ \\ ${ }^{1}$ Institute of Geriatric Medicine, ${ }^{2}$ Cardiovascular Diseases Center, Xiyuan Hospital of China Academy of Chinese Medical Sciences, Beijing 100091, \\ China; ${ }^{3}$ Beijing University of Chinese Medicine, Beijing 100029, China; ${ }^{4}$ School of Chinese Medicine, Faculty of Medicine, The Chinese University \\ of Hong Kong, Shatin, N.T., Hong Kong, China \\ Contributions: (I) Conception and design: F Xu, Z Lin, Y Liu; (II) Administrative support: F Xu, Z Lin; (III) Provision of study materials: J Zhao, X \\ Lan; (IV) Collection and assembly of data: J Zhao, X Lan; (V) Data analysis and interpretation: J Zhao, Y Xian, Y Liu; (VI) Manuscript writing: All \\ authors; (VII) Final approval of manuscript: All authors. \\ Correspondence to: Prof. Fengqin Xu. Institute of Geriatric Medicine, Xiyuan Hospital of China Academy of Chinese Medical Sciences, Beijing \\ 100091, China. Email: dr.xufengqin@outlook.com; Prof. Zhixiu Lin. School of Chinese Medicine, Faculty of Medicine, The Chinese University of \\ Hong Kong, Shatin, N.T., Hong Kong, China. Email: linzx@cuhk.edu.hk.
}

\begin{abstract}
The aging of the population has become a global health problem. It is an important risk factor for major diseases such as cardiovascular disease, Alzheimer's disease, Parkinson's disease, and cancer. Presently, there is no definite and effective anti-aging treatment. Chinese herbal medicine has a long history of application and is often used for aging-related diseases in China. A large number of clinical and preclinical studies on the anti-aging effect of Chinese herbal medicine has been performed. Through literature research, we reviewed the anti-aging clinical research of Chinese herbal medicine and preclinical research of Chinese herbal medicine monomers, components, extracts, and compounds, and their mechanisms. Results from preclinical studies have shown that Chinese herbal medicines have beneficial anti-aging effects. The mechanism mainly includes anti-oxidative stress, anti-inflammatory, neuroprotection, apoptosis and mitochondrial function regulation, etc. However, more detailed high-quality clinical trials are required for future investigation of the anti-aging effects of Chinese herbal medicines.
\end{abstract}

Keywords: Chinese herbal medicine (CHM); evidence; mechanism; review; anti-aging

Submitted Aug 20, 2019. Accepted for publication Feb 14, 2020.

doi: 10.21037/apm.2020.04.09

View this article at: http://dx.doi.org/10.21037/apm.2020.04.09

\section{Introduction}

With the improvement of science and technology and living conditions, mankind is gradually moving towards an aging society. According to the United Nations World Population Ageing Report released in 2015 (1), the number of aged people (60 and over) is expected to increase to nearly 2,100 million over the next 35 years. As age increases, the physiological function of the body gradually deteriorates, which is characterized by the decline in the structure and function of organs, cells, and tissues (2). Aging-related diseases are becoming one of the biggest challenges faced by developed and developing countries (3). López-Otínput forwarded nine pathological features of aging, including genomic instability, telomere loss, epigenetic changes, protein homeostasis imbalance, deregulated nutrient sensing, mitochondrial damage, cell senescence, stem cell exhaustion, and intercellular communication changes (4).

Presently, anti-aging methods mainly include diet restriction, gene reprogramming, and drugs (5). A growing number of research data shows that adequate dietary restrictions (DR) have a strong protective effect on obesity, type 2 diabetes, inflammation, hypertension, and cancerrelated risk factors under sufficient nutrition (6). In fact, for most people, the duration and degree of the DR program needed for the best benefit are unfeasible and may lead 
to related side effects. Short term partial reprogramming of Oct4, Sox2, Klf4, and c-Myc (OSKM) improves physiological markers in mice, prolongs their life span, and improves the muscle regeneration ability of the normal old mice (7). However, the feasibility and safety of these two methods need further studies.

Drug therapy is an anti-aging method, and rapamycin, metformin, and spermidine are the typical drugs. Rapamycin, an mTOR inhibitor, can reduce downstream production of mTOR $\mathrm{c} 1$ and S6K by inhibiting the mTOR pathway; the life span of mice can be prolonged by up to $60 \%$ with 3 months of rapamycin treatment (8). A study was performed to assess whether the mTOR inhibitor RAD001, could improve immune senility to influenza vaccination in elderly volunteers. The results showed that RAD001 enhanced immune response to influenza vaccines and also reduced the percentage of $\mathrm{CD}^{+}$and $\mathrm{CD} 8^{+} \mathrm{T}$ lymphoblastic cells that expressed the programmed death-1 receptor (PD-1) (9). Metformin, a usual drug used in type 2 diabetes mellitus (T2DM) treatment, has been proven to prolong the life span of nematodes (10). Spermidine, a natural polyamine, can prolong the life of mice and play a protective role in the heart by reducing myocardial hypertrophy and protecting the diastolic function of the heart in aged mice (11). Additionally, low dose lithium can prolong the life span of Drosophila melanogaster by $16 \%$; the mechanism may be related to its glycogen synthetase kinase-3 (GSK-3) inhibition and transcription factor nuclear factor erythroid 2-related factor (NRF-2) activation (12).

However, sufficient clinical evidence of the effects of theses drugs on humans is unavailable. In recent years, the anti-aging effect of Chinese herbal medicine (CHM) has been widely and deeply researched. This article is an overview of the progress on elucidating the anti-aging effects of CHM. The research articles of anti-aging CHM published from 2008 to 2018 were retrieved from PubMed. The Clinical Trials (https://clinicaltrials.gov/) and Chinese Clinical Trial Registry (http://www.chictr.org.cn/) databases were searched for registered clinical trials.

\section{The anti-aging role of CHM}

\section{Evidence from clinical studies in bumans}

Nine clinical trials published from 2008 to 2018 were included (Table 1). The types of studies include randomized controlled trials, crossover trials, cohort studies, etc. Resveratrol was the most studied medicine, followed by curcumin. The main outcome indicators of these clinical studies were as follows: general signs, muscle function and structure, cardiovascular and metabolic indicators, cognitive function, aging-related protein or gene, and safety indicators.

Some studies reported the following adverse reactions: gastrointestinal reactions, dizziness, diarrhea, constipation, muscle cramps, fatigue, memory loss, allergies, difficulty swallowing, rash, headache, etc. In a randomized, doubleblind crossover study of resveratrol, three participants treated with $3 \mathrm{~g}$ of resveratrol daily experienced severe gastrointestinal symptoms with one requiring hospitalization, but when the dose was lowered to $2 \mathrm{~g} / \mathrm{d}$ for the remaining participants, no further gastrointestinal symptoms were reported (13). Resveratrol supplementation at doses of 300 and $1,000 \mathrm{mg} /$ day for 90 days does not adversely affect blood chemistry, and is well tolerated in overweight and older individuals; the incidence of adverse events between the treatment and control groups was not statistically significant (14). This study highlights the safety of short-term and low-dose resveratrol administration. In terms of anti-aging, research shows that resveratrol combined with exercise can reduce or reverse sarcopenia in elderly persons (15). Besides, supplementary resveratrol also improves memory performance and increases hippocampal functional connectivity in healthy older adults; improved glucose metabolism may be an underlying mechanism (16). Another study also showed that a single dose of $75 \mathrm{mg}$ of resveratrol improves neurovascular coupling and cognitive function in patients with T2DM (17). However, a prospective study in 783 older community-dwelling adults showed that there was no association between urinary resveratrol metabolites and longevity; total urinary resveratrol metabolite concentration was not associated with inflammatory markers, cardiovascular disease, cancer, or all-cause mortality (18). Therefore, further clinical research on the anti-aging effect of resveratrol is waranted. On the other hand, curcumin $(2,000 \mathrm{mg} /$ day $)$ administration for 12 weeks improves resistance artery endothelial function by increasing vascular nitric oxide bioavailability and reducing oxidative stress (19). A 12-month, randomized, placebo-controlled, double-blind study focused on curcumin and cognition showed that there were no differences in cognitive performance from baseline to the 12-month follow-up between placebo and treatment groups (20). Ganoderma lucidum has been used as a traditional medicine to treat a variety of diseases. A randomized, doubleblind, placebo-controlled crossover study on Ganoderma lucidum shows its antioxidation and hepatoprotective efficacy, but the subjects were healthy middle-aged (40-54 years old) 
Table 1 Published clinical trials of CHM for slowing aging in humans from 2008 to 2018

\begin{tabular}{|c|c|c|c|c|c|c|c|}
\hline Age & Medicine & Dose & Duration & Case & Main outcomes & Adverse events & References \\
\hline$\geq 65$ & Resveratrol & NA & 9 years & 783 & $\begin{array}{l}\text { All-cause mortality, CRP, } \\
\text { TNF- } \alpha \text {, IL-6, IL-1 } \beta \text {, prevalent } \\
\text { and incident cancer, and } \\
\text { cardiovascular diseases }\end{array}$ & No reports & (18) \\
\hline $50-80$ & Resveratrol & $2-3 \mathrm{~g} / \mathrm{d}$ & 6 weeks & 30 & $\begin{array}{l}\text { Cardiometabolic, endothelial } \\
\text { function, and skeletal muscle } \\
\text { gene expression }\end{array}$ & Gastrointestinal symptoms & (13) \\
\hline $40-80$ & Resveratrol & $\begin{array}{l}75,150, \text { and } \\
300 \mathrm{mg} / \mathrm{d}\end{array}$ & NA & 36 & $\begin{array}{l}\text { Neurovascular coupling } \\
\text { capacity }\end{array}$ & No reports & $(17)$ \\
\hline $45-74$ & Curcumin & $0.2 \mathrm{mg} / \mathrm{d}$ & 12 weeks & $20 / 19$ & $\begin{array}{l}\text { Artery endothelial function, } \\
\text { vascular nitric oxide } \\
\text { bioavailability, and oxidative } \\
\text { stress }\end{array}$ & $\begin{array}{l}\text { Diarrhea, dizziness, and } \\
\text { nausea gastrointestinal }\end{array}$ & (19) \\
\hline $40-90$ & Curcumin & $0.15 \mathrm{~g} / \mathrm{d}$ & 12 months & $80 / 80$ & Montreal cognitive assessment & Gastrointestinal & (20) \\
\hline
\end{tabular}

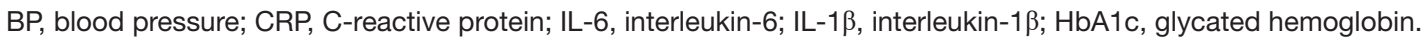

volunteers (21), therefore, its efficacy in the elderly should be further studied.

Additionally, we found 10 registered clinical trials (Table 2) from Clinical Trials (https://clinicaltrials.gov) and Chinese Clinical Trial Registry (http://www.chictr.org.cn), the recruiting locations are mainly China and the United States. Generally, large-scale clinical research on the antiaging effect of CHM remains unavailable. Presently, there are still some shortcomings in clinical research such as fewer cases, short follow-up time, etc.

\section{Evidence from Preclinical Studies}

In this section, we summarize the known effects, and mechanisms of single herbs and their components or extracts in preclinical studies (Tables 3 and 4).

\section{Monomers and Components of CHM Resveratrol}

Resveratrol is a natural polyphenolic compound found in several plants, including grapes and Polygonum cuspidatum (79). Studies have shown that it indirectly activates SIRT1 in vivo (80). The life-prolonging metabolic roles of SIRT1 include gluconeogenesis regulation, fatty acid oxidation reduction, fat production reduction, insulin secretion upregulation, and autophagy regulation (81). Additionally, resveratrol can alleviate $\mathrm{H}_{2} \mathrm{O}_{2}$-induced oxidative stress injury in endothelial cells, thereby slowing aging (82). Resveratrol can also protect against arterial aging, and this effect is associated with reduced activity of 
Table 2 The ongoing RCTs of CHM for slowing aging from 2008 to 2018

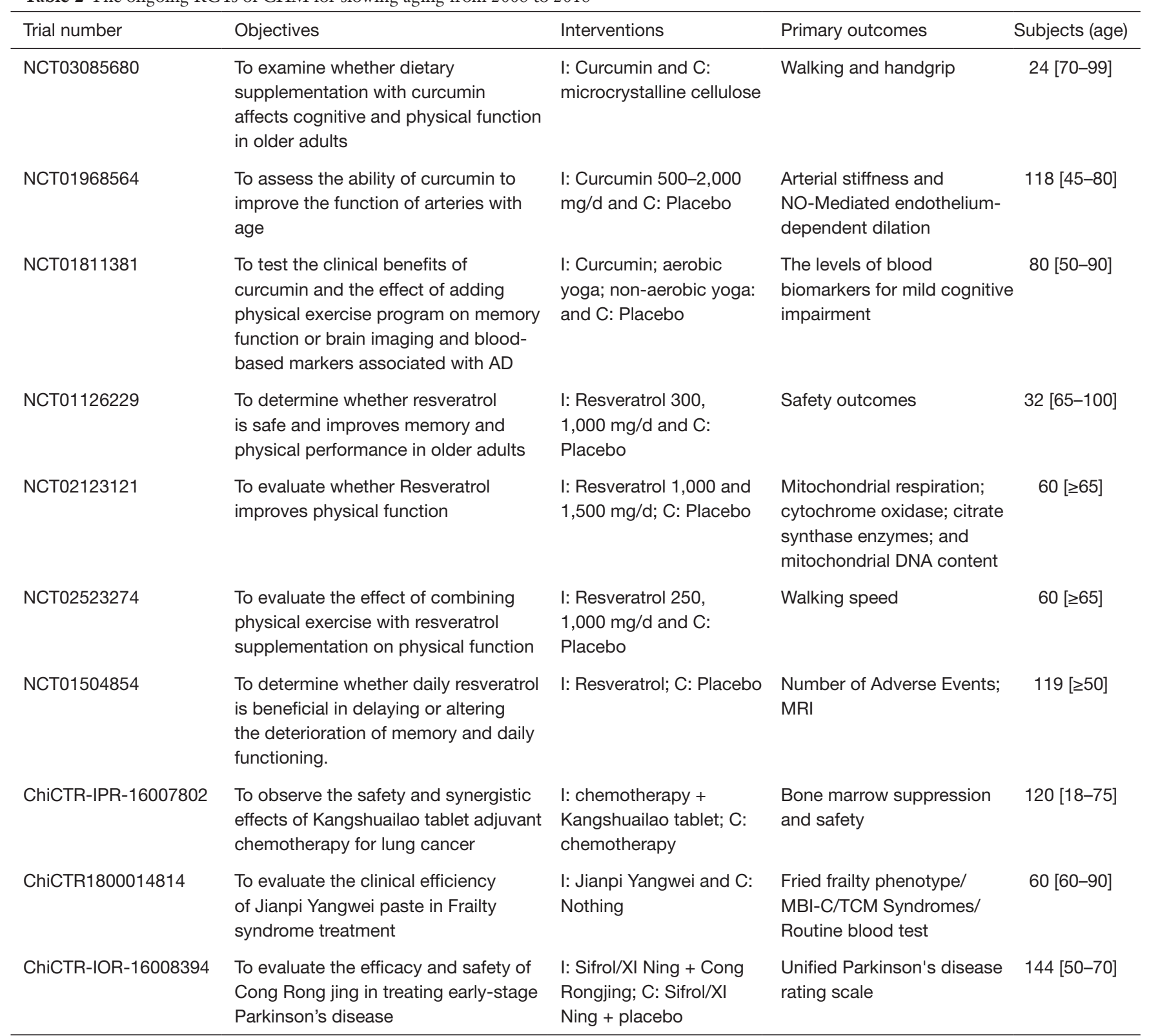

the PRR-ACE-Ang II axis and stimulation of the ACE2Ang-(1-7)-ATR2-MasR axis (83).

\section{Curcumin}

Curcumin is a bioactive substance extracted from the rhizome of Curcuma longa L (84). Curcumin supplementation can increase the survival rate of Drosophila, which may be related to its antioxidant activities and the mitigating effect of heat shock responses (85). Another study showed that curcumin suppresses vascular aging and inflammation triggered by long-term administration of a high-fat diet, which might be a prophylactic food against arteriosclerotic disease (86). Aging is the major risk factor for osteoarthritis and studies have found that curcumin can treat it by inducing autophagy via the Akt/mTOR signaling pathway (87).

\section{Ginsenoside $\operatorname{Rg} 1$}

Ginsenoside $\mathrm{Rg} 1$, an active ingredient of Panax ginseng, can improve the cognitive ability of the D-galactose-induced aging rat model; its mechanism may be related to neural stem/progenitor cell protection, and antioxidant and antiinflammatory capacity enhancement in the hippocampus (88). 


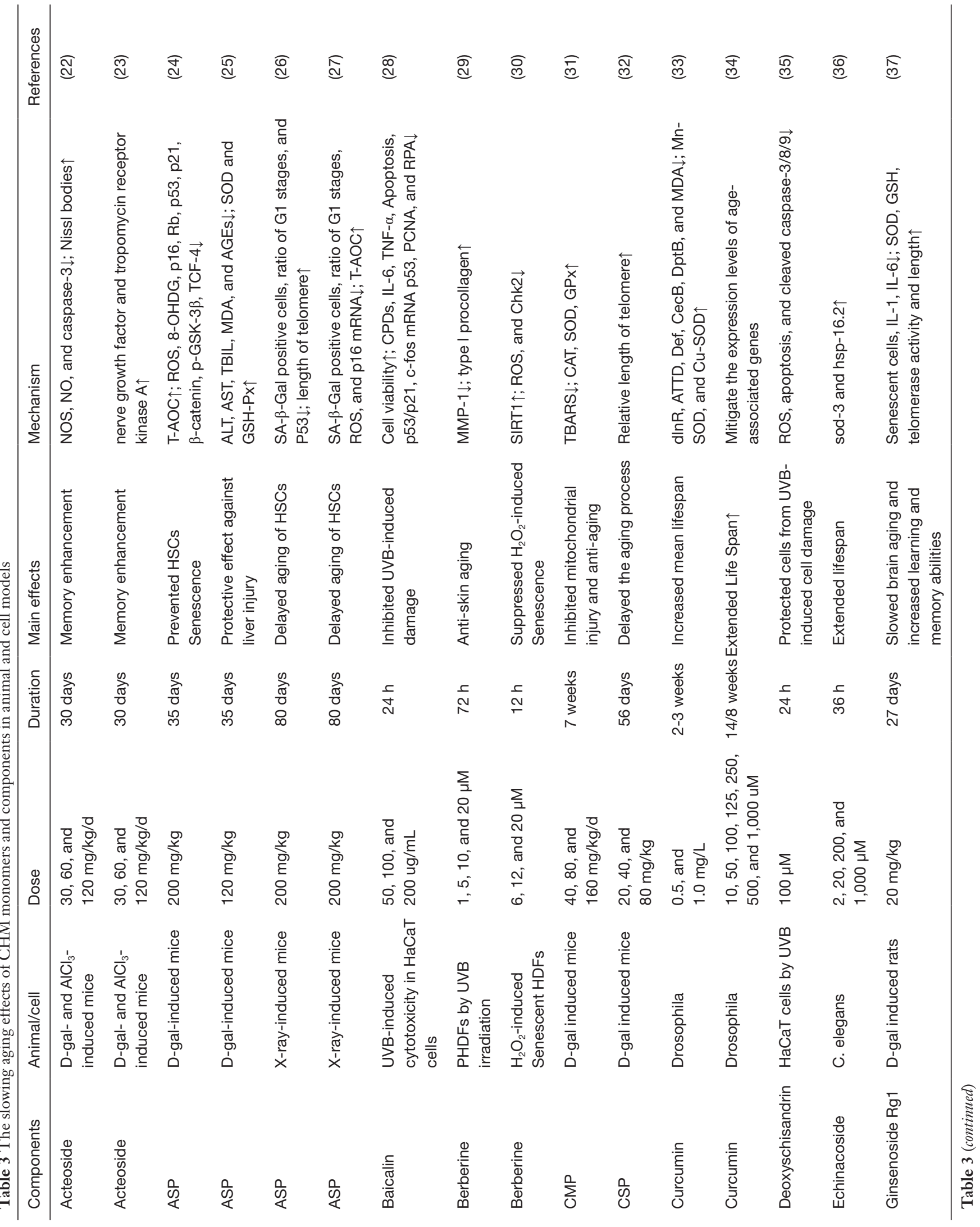




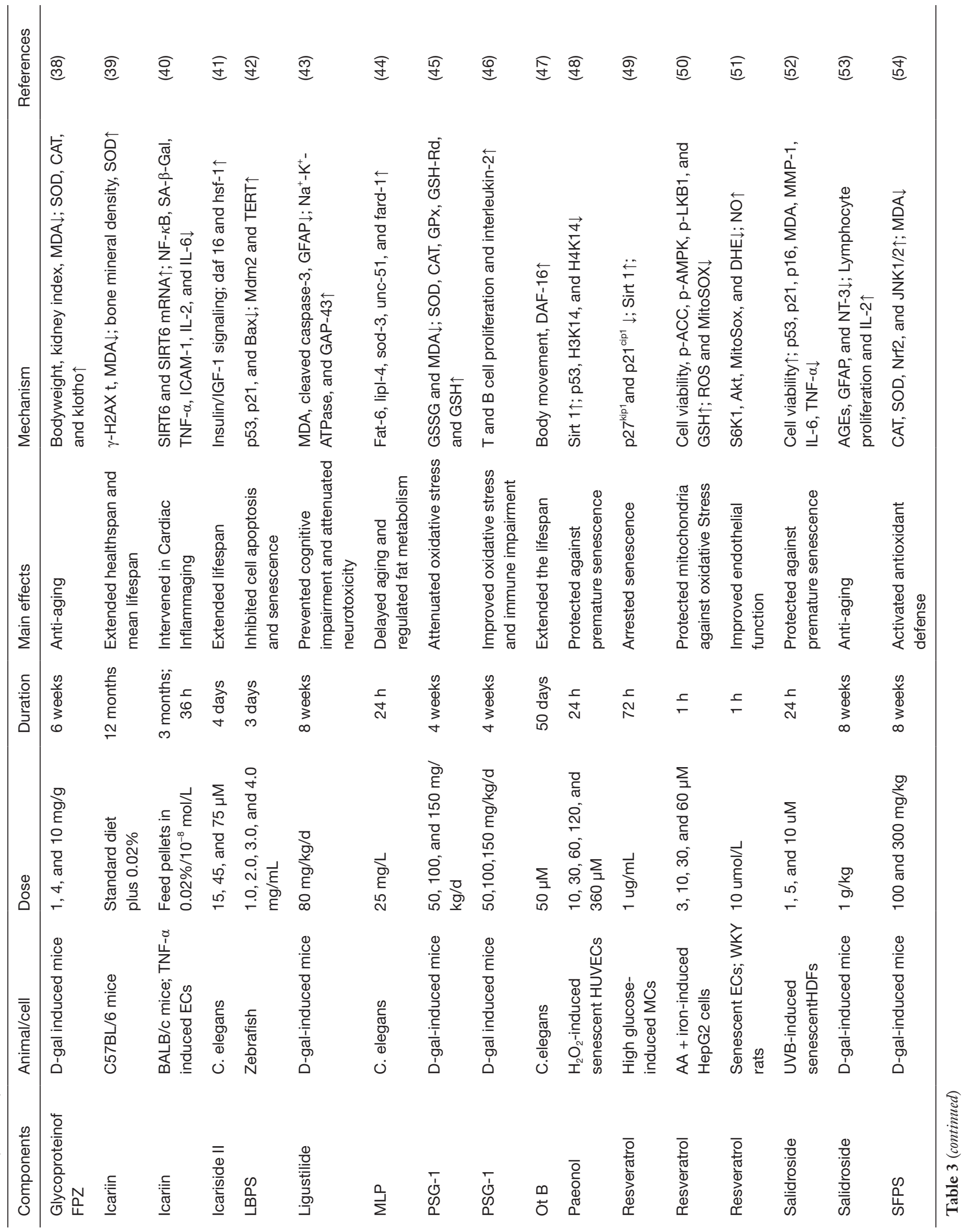




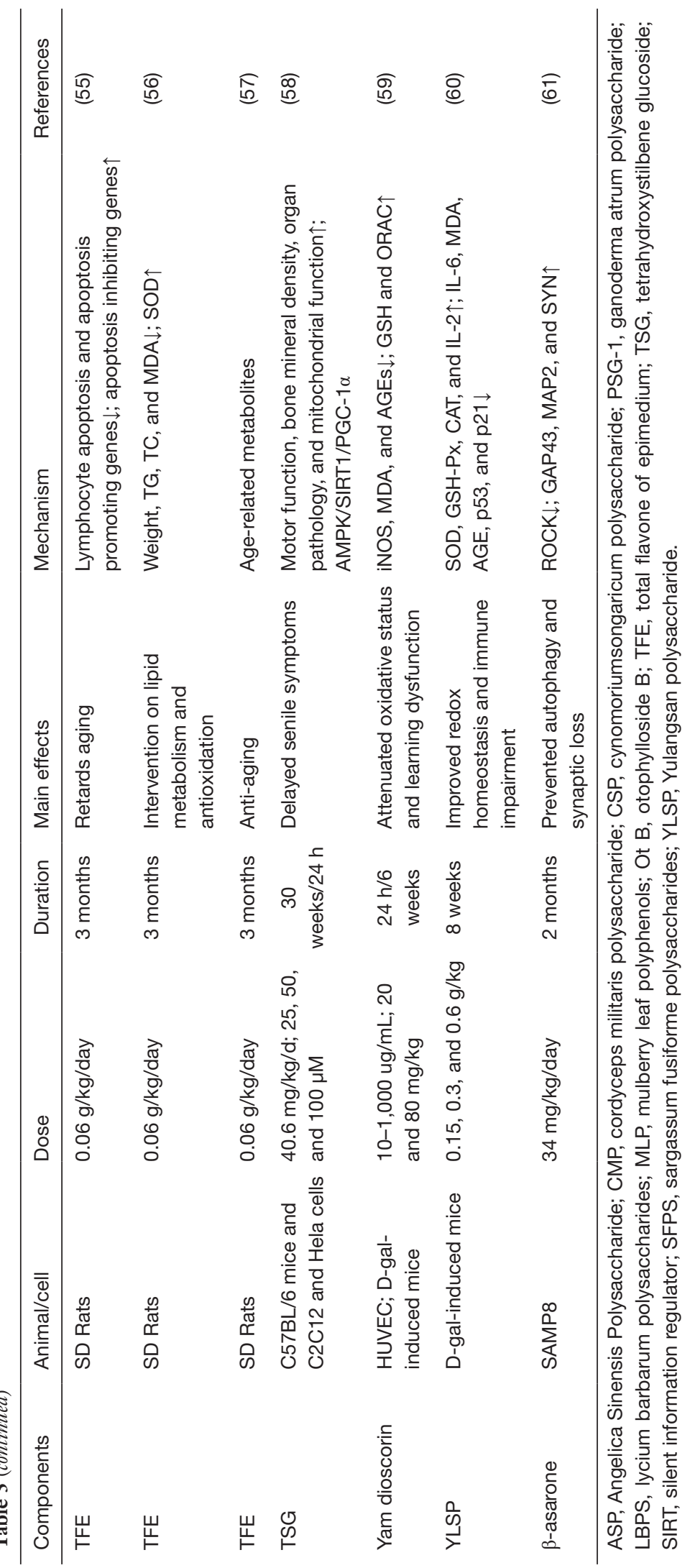




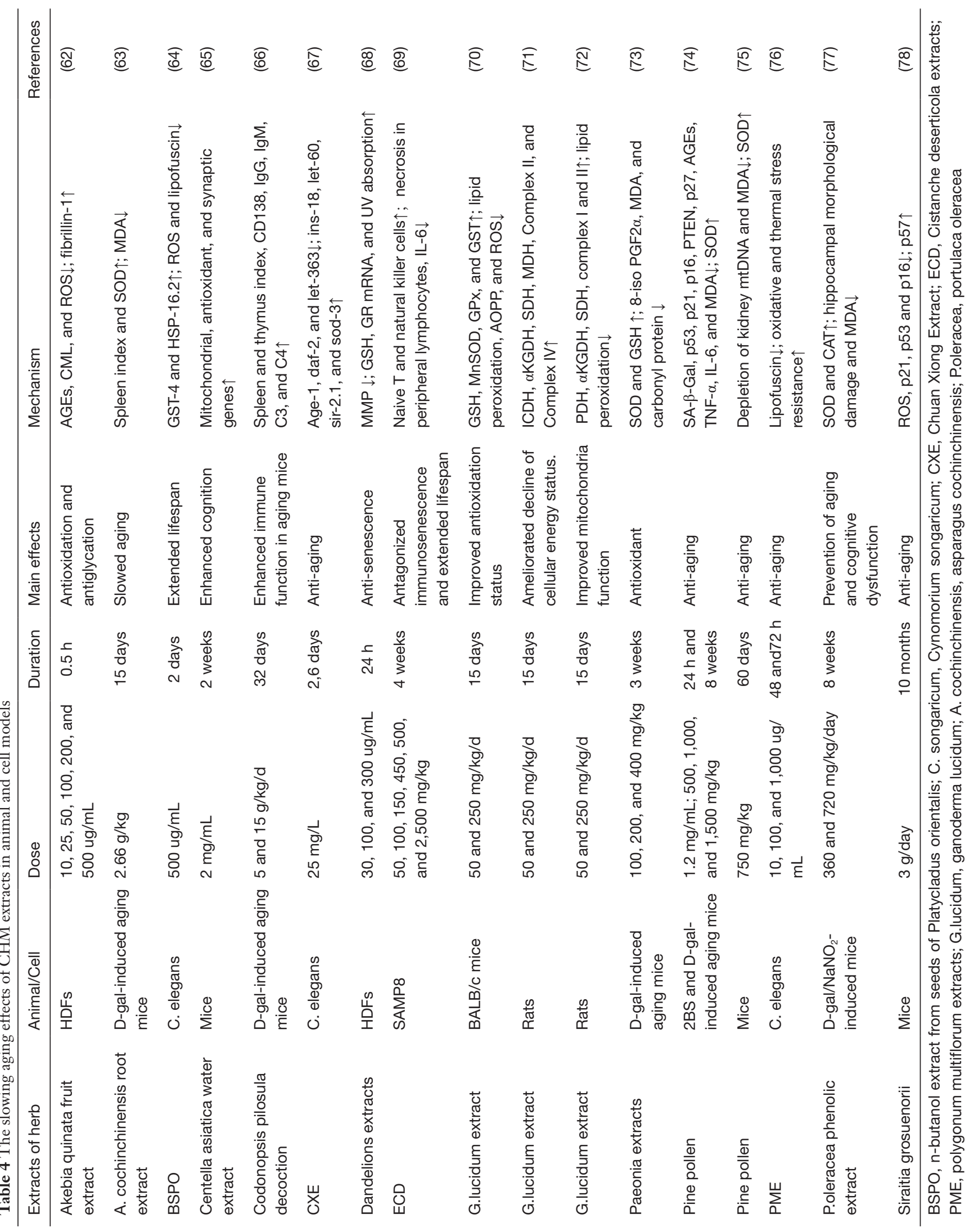


Later studies showed that its protective effect may be achieved via downregulation of the $\mathrm{p} 19 / \mathrm{p} 53 / \mathrm{p} 21$ signaling pathway (89). Hematopoietic stem cell (HSC) senescence is an important hypothesis accounting for organismal aging; Ginsenoside $\mathrm{Rg} 1$ can improve the resistance of $\mathrm{Sca}-1^{+}$ hematopoietic stem/progenitor cells (HSC/HPCs) in aging mice by reducing DNA damage and inhibiting excessive activation of the $\mathrm{Wnt} / \beta$-catenin signaling pathway (90). The function of the spleen and thymus decreases with aging; Ginsenoside $\operatorname{Rg} 1$ can protect the spleen and thymus of $\mathrm{D}$-galactose-induced aging rats via reducing oxidative stress injury and downregulating the expression of aging-related proteins (91).

\section{Salidroside}

Salidroside, a phenylpropanoid glycoside, is a potent component isolated from the root of Rhodiola rosea, which can resist immune aging by enhancing humoral and cellmediated immune responses in aged rats after antigen activation (92). Besides, salidroside can also play a therapeutic role in learning and memory decline by stimulating cAMP response element binding protein (CREB)-dependent functional neurogenesis during aging (93). Aging is the major risk factor for cardiovascular diseases, especially coronary atherosclerosis, which is mainly attributed to the aging of vascular structure and function. Studies showed that salidroside can prevent oxidized low-density lipoprotein (ox-LDL)induced endothelial cell senescence by promoting the cell cycle and reducing intracellular lipid deposition, inhibiting the expression of senescence-related molecules (94).

\section{Total Flavonoid of Epimedium and Icariin}

Epimedium is the dry leaf of Epimedium brevicornu Maxim (95). Its main constituents are the Total Flavonoid of Epimedium (TFE) and Icariin. Oxidative stress is one of the main causes of aging and can induce oxidative DNA damage, causing cell cycle arrest and apoptosis; however, TFE can effectively reduce oxidative stress-induced DNA damage in aging rats by inhibiting p-p53/p21 and chk1/chk2 expression, increasing superoxide dismutase (SOD) activity and decreasing malondialdehyde (MDA) content (96). Icariin alleviates the age-dependent deficit in cognitive function, which may be via activation of neural stem cells (NSCs) in the hippocampus (97). Parkinson's disease (PD) is one of the most common neurodegenerative diseases. Two different damage models of dopamine neurons in rat midbrain induced by neurotoxins of 6-hydroxydopamine (6OHDA) and lipopolysaccharide (LPS) were employed to investigate the neuroprotective effects of Icariin. The result showed that it could protect dopamine neurons both in vivo and in vitro, and the mechanism may be related to the inhibition of microglia-mediated neuroinflammation (98).

\section{Angelica Sinensis Polysaccharide}

Angelica Sinensis (Dang gui) is the dry root of an umbelliferous plant Angelica sinensis (Oliv.) Diels (95). Angelica Sinensis Polysaccharide (ASP) is a major ingredient in Angelica Sinensis. ASP ameliorated stress-induced premature senescence of hematopoietic cells by protecting bone marrow stromal cells against chemotherapeutic injury via alleviating the oxidative damage of stromal cells and improving their hematopoietic function (99).

\section{Astragalus polysaccharides (APS)}

APS is a major active ingredient of Astragalus membranaceus. Bone marrow mesenchymal stem cell (BMSCs) dysfunction under pathological stimulation is involved in the development of aging-related diseases such as osteoporosis (100). APS treatment may attenuate apoptosis and senescence in BMSCs, inhibiting the reduction of Nanog, Sox2, and Oct4 expression caused by ferric ammonium citrate (FAC) (100).

\section{Echinacoside (ECH)}

$\mathrm{ECH}$ is a phenylethanoid glycoside isolated from Cistanche tubulosa, found to extend the life span of worms, increase their tolerance to heat shock and oxidative stress, and modulate the nuclear localization and transcriptional activities of daf-16 (101).

\section{Tetrahydroxystilbene glucoside and emodin}

2,3,5,4'-tetrahydoxystilbene-2-O- $\beta$-D-glucoside (TSG) is a major bioactive constituent of Polygonum multiflorum Thunb. Several studies have indicated that TSG exerts a marked neuroprotective effect against glutamate-induced hippocampal damage by decreasing ROS production and stabilizing mitochondrial membrane potential (MMP) (102). TSG enhanced hippocampal-dependent contextual fear memory and novel object recognition probably via promoting phosphorylation of ERK1/2, CaMKII, and CREB, upregulation of silent information regulator 1 (SIRT1), and downregulation of miR-134 (103). Emodin, an active component of Polygonum multiflorum Thunb, may exert a significant neuroprotective effect by activating the PI3K/Akt signaling pathway against glutamate-induced apoptosis and improving behavioral function in cerebral ischemia (104). However, attention should be paid to its toxicity, especially hepatic adverse reactions (105).

\section{Others}

Other preclinical studies on the anti-aging effects of the 
monomers and components of CHM are shown in Table 3.

\section{Extracts of CHM}

\section{Ganoderma lucidum (Ling Zbi)}

Ganoderma lucidum is the dried fruiting body of Ganoderma lucidum (Leyss. ex Fr.) Karst. or Ganoderma sinense (95). Ganoderma lucidum extracts play a role in ameliorating DNA damage (106), which is a major causes of aging. Since oxidative stress also plays an important role in the aging process, researchers accessed its ability to protect bladder function from ischemia/reperfusion (I/R)-mediated oxidative damage, and found that Ganoderma lucidum, prior to $\mathrm{I} / \mathrm{R}$, can completely inhibit the negative effects of I/R (107).

\section{Cistanches herba (Rou Cong Rong)}

Cistanches is the dry-sliced fleshy stem of Cistanche deserticola Y.C. Ma or Cistanche tubulosa (Schenk) Wight. Cistanche deserticola can improve the age-related behavioral decline and pathological manifestations of cataract and retinopathy in rats (108). Cistanche tubulosa extends the lifespan and increases the flies' resistance to oxidative stress, and enhances memory formation in young flies (109).

\section{Cynomorium songaricum (Suo Yang)}

Cynomorium songaricum (CS) is a dry fleshy stem of Cynomorium songaricum Rupr (95). Research shows that it extends both the mean and maximum lifespan of adult female flies by improving antioxidant stress ability (110). The ethyl acetate fraction of CS attenuated staurosporineinduced SK-N-SH neuroblastoma cell death (111). The flavonoid extract of CS shows antioxidant and anti-fatigue effects on the swimming endurance of rats; free radical scavenging enzymes increase after treatment with the flavonoid extract (112).

\section{Alpiniae oxyphyllae fructus (Yi Z Zi)}

Alpiniae oxyphyllae fructus is the dried and ripe fruit of Zingiberaceae plant Alpinia oxyphylla Miq. (95). Cardiac hypertrophy is a pathophysiological phenomenon associated with aging. Research has proven that Alpiniae oxyphyllae fructus (AOF) can improve aging-related cardiovascular diseases such as myocardial remodeling and cardiac hypertrophy. It inhibits apoptosis in the cardiac tissue of SD rats by regulating apoptosis-related genes and activating the longevity factor SIRT1 (113). Further research shows that AOF protects against cardiac hypertrophy in the D-galactose-induced senescent rat model via downregulation of both concentric and eccentric hypertrophy signaling pathways such as ERK1/2/JNK (114). Others

Other preclinical studies on the anti-aging effect of CHM extracts are shown in Table 4.

\section{CHM compounds}

Researchers studied the anti-aging effect and mechanism of eight kinds of CHM compounds (Liu Wei Di Huang Wan, Qi Bao Mei Ran Dan, Shi Quan Da Bu Wan, Sheng Mai Yin, Er Chen Wan, Huan Shao Dan, Qin Jiao Wan, and Tian Ma Wan) on Caenorbabditis elegans and found that their mechanism was partially related to antioxidative and thermal stress effect (115). Researchers firstly focused on the expression of related proteins (STUB1, CaMKII AMFR) in Alzheimer's disease (AD), and then studied the effect of CHM compounds on their expression (116-118).

\section{Liu Wei Di Huang}

Liu Wei Di Huang (LW) is a typical traditional Chinese medicine (TCM) prescription, consisting of six herbs. It has long been clinically used to treat many kinds of agingrelated diseases. It was demonstrated to ameliorate the decline of learning and memory in senescence-accelerated mouse/prone 8 (SAMP8); improvement of the synaptic plasticity via inhibiting voltage-dependent calcium channels and promoting N-Methyl-d-aspartate receptor function may be one of the mechanisms (119). Senescence-accelerated mouse/prone 8 (SAMP8) is considered a robust experimental model for AD. LW-AFC was prepared from Liu Wei Di Huang decoction and included polysaccharides, glycosides, and oligosaccharides. Research shows it can ameliorate cognitive impairment by altering gene expressions and regulating pathways in the hippocampus (120). Aqueous LW extract shows potential benefits for PD treatment in both primary mesencephalic neuron cells and MPTP-treated C57BL/6 mice (121).

\section{Dang Gui Shao Yao San}

Dang Gui Shao Yao San (DSS) was originally described in Dong Han Dynasty, ancient China. JD-30 is a fraction extracted from DSS and is able to improve synaptic plasticity and ameliorate deterioration of cognition by blocking and disrupting $A \beta$ aggregation (122). Simultaneously, the elevation of estradiol, NO, and glycine levels in blood plasma may contribute to the cognitive improvement effects of DSS (123). Systems pharmacology research indicated that DSS treats neurodegenerative diseases and other diseases, as determined through research on the same pathological proteins involved in these diseases (124). Additionally, DSS has been proven to promote angiogenesis and neurogenesis after ischemic stroke (125). In conclusion, DSS has great potential in the treatment of neurodegenerative diseases, especially $\mathrm{AD}$, and needs further study. 


\section{Zuo Gui Yin}

Zuo Gui Yin/Wan is one of the TCM prescriptions from a classical TCM book named "Jing Yue Quan Shu". Bone mineral density was enhanced markedly in ovariectomized mice and naturally aged mice after Zuo Gui Wan administration. This result shows that it has an antiaging activity (126). In terms of neuroprotection, Zuo Gui Wan promoted the recovery of neurological function by abrogating inflammation via regulating $\operatorname{NogoA}, \mathrm{NgR}$, and RhoA levels, and other neurotrophic factors (127).

\section{Bu Shen Yi Zbi formula}

Bu Shen Yi Zhi (BSYZ) formula, a traditional CHM compound composed of Fructus Cnidii (She Chuang Zi), Panax ginseng (Ren Shen), Polygonum multiflorum (Shou $\mathrm{Wu}$ ), Cortex moutan (Mu Dan Pi), Ligustrum lucidum (Nv Zhen Zi), and Fructus lycii (Gou Qi Zi), has been well-researched by Chinese research teams, especially its neuroprotection effect. Neuroinflammation is considered to be an important mediator in the pathogenesis and progression of PD. BSYZ is thought to alleviate 1-methyl4-phenyl-1, 2, 3, 6-tetrahydropyridine (MPTP)-induced neuroinflammation by inhibiting the activation of NLRP3 inflammasome in microglia (128). Additionally, the acetate extract components of BSYZ provide neuroprotection against scopolamine (SCOP)-induced cognitive dysfunction by inhibiting oxidative stress and apoptosis (129). In a recent study, the team used a systems pharmacology approach to investigate the active ingredients of BSYZ and potential targets in $\mathrm{AD}$, and on this basis established the APPswe/PSEN1dE9 transgenic mouse model to validate the proposed mechanisms for BSYZ. The results showed that the effects of BSYZ on cognitive dysfunction may be related to the regulation of amyloid- $\beta$ metabolism and neuronal apoptosis (130).

\section{Others}

Other preclinical studies on the anti-aging effect of CHM compounds are shown in Table 5.

\section{Concluding remarks}

In summary, no theory can fully explain the complex process of aging as it is multifactorial. In recent years,

Table 5 The slowing aging effects of CHM compounds in animal and cell models

\begin{tabular}{|c|c|c|c|c|c|c|}
\hline Compound & Model & Dose & Duration & Effects & Mechanism & References \\
\hline $\begin{array}{l}\text { Bu Shen Yi Zhi } \\
\text { formula }\end{array}$ & SAMP8 & $\begin{array}{l}1.46,2.92, \text { and } \\
5.84 \mathrm{~g} / \mathrm{kg} / \mathrm{d}\end{array}$ & 4 weeks & $\begin{array}{l}\text { Ameliorated cognitive } \\
\text { dysfunction, neuronal } \\
\text { apoptosis, and ER stress }\end{array}$ & $\begin{array}{l}\text { AChE, Caspase-3, Bax/ } \\
\text { Bcl-2, Perk, BIP, PDI, and } \\
\text { CHOP } \downarrow \text {; ChAT, Ach, and } \\
\text { SIRT1 }\end{array}$ & (132) \\
\hline $\begin{array}{l}\text { Bu Shen Yi Zhi } \\
\text { formula }\end{array}$ & SAMP8 & $\begin{array}{l}1.46,2.92, \text { and } \\
5.84 \mathrm{~g} / \mathrm{kg} / \mathrm{d}\end{array}$ & 30 days & $\begin{array}{l}\text { Attenuated cognitive } \\
\text { impairment and } \\
\text { inflammation, oxidative } \\
\text { stress, and neuronal } \\
\text { apoptosis }\end{array}$ & 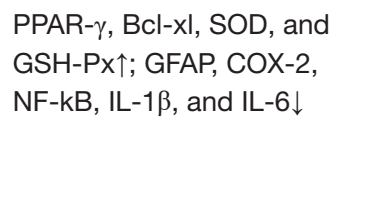 & (133) \\
\hline $\begin{array}{l}\text { Dang Gui Shao } \\
\text { Yao San }\end{array}$ & $\begin{array}{l}\text { D-gal-induced } \\
\text { aging mice }\end{array}$ & $\begin{array}{l}1.8,3.6, \text { and } \\
7.2 \mathrm{~g} / \mathrm{kg}\end{array}$ & 6 weeks & $\begin{array}{l}\text { Ameliorated cognition } \\
\text { deficits }\end{array}$ & 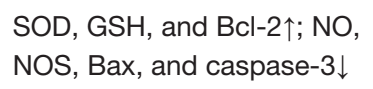 & (135) \\
\hline $\begin{array}{l}\text { Dang Gui Shao } \\
\text { Yao San }\end{array}$ & SAMP8 & $\begin{array}{l}0.7,1.4, \text { and } \\
2.8 \mathrm{mg} / \mathrm{mL}\end{array}$ & 8 weeks & $\begin{array}{l}\text { Improved spatial learning } \\
\text { and memory }\end{array}$ & $\begin{array}{l}\text { LTP and Nissl-positive cell } \\
\text { densities } \uparrow ; A \beta \downarrow\end{array}$ & (136) \\
\hline Fu Zhi San & SAMP8 & $\begin{array}{l}0.3,0.6, \text { and } \\
1.2 \mathrm{~g} / \mathrm{kg} / \text { day }\end{array}$ & 8 weeks & $\begin{array}{l}\text { Ameliorated memory } \\
\text { deficits }\end{array}$ & $\begin{array}{l}\text { A } \beta, \text { BACE } 1, \beta-C T F, p-T a u \\
\text { and } p-25 \downarrow\end{array}$ & (137) \\
\hline
\end{tabular}

Table 5 (continued) 
Table 5 (continued)

\begin{tabular}{|c|c|c|c|c|c|c|}
\hline Compound & Model & Dose & Duration & Effects & Mechanism & References \\
\hline $\begin{array}{l}\text { Huang Lian Jie } \\
\text { Du decoction }\end{array}$ & SAMP8 & $15 \mathrm{~g} / \mathrm{kg} / \mathrm{d}$ & 1 month & $\begin{array}{l}\text { Ameliorated cognitive } \\
\text { impairment }\end{array}$ & $\begin{array}{l}\text { Regulation of gene } \\
\text { expression patterns }\end{array}$ & $(140)$ \\
\hline Kun Tai capsule & $\begin{array}{l}\text { Accelerated } \\
\text { aging ovary } \\
\text { model }\end{array}$ & $\begin{array}{l}0.4,0.8, \text { and } \\
1.6 \mathrm{~g} / \mathrm{kg}\end{array}$ & 4 weeks & $\begin{array}{l}\text { Regulated the estrous } \\
\text { cycles, increased hormone } \\
\text { secretion and fertility, and } \\
\text { decreased atretic follicles }\end{array}$ & $\begin{array}{l}\mathrm{AMH}, \mathrm{SOD} 2 \text {, and } \mathrm{Bcl}-2 \uparrow ; \\
\mathrm{Bax} \downarrow\end{array}$ & $(141)$ \\
\hline $\begin{array}{l}\text { LWDH ethanol } \\
\text { extract }\end{array}$ & C. elegans & $0.1-2 \mathrm{mg} / \mathrm{mL}$ & $36 \mathrm{~h}$ & $\begin{array}{l}\text { Alleviated } \beta \text {-amyloid- } \\
\text { induced toxicity }\end{array}$ & ROS $\downarrow$; heat shock protein $\uparrow$ & $(142)$ \\
\hline LWDH & SAMP8 & $1.6 \mathrm{~g} / \mathrm{kg} / \mathrm{d}$ & 5.5 months & $\begin{array}{l}\text { Improved cognitive } \\
\text { impairments }\end{array}$ & $\begin{array}{l}\text { Modulating intestinal } \\
\text { microbiome }\end{array}$ & $(144)$ \\
\hline RRF & Natural aging rat & $\begin{array}{l}141,282, \text { and } \\
564 \mathrm{mg} / \mathrm{kg} / \mathrm{d}\end{array}$ & 16 weeks & Ameliorated perimenopause & $\begin{array}{l}\mathrm{FSH} \downarrow \text {; estradiol, } \\
\text { hypothalamic dopamine, } \\
\text { and norepinephrine } \uparrow\end{array}$ & $(145)$ \\
\hline $\begin{array}{l}\text { Shi Quan Da Bu } \\
\text { Tang }\end{array}$ & C. elegans & $100 \mathrm{ug} / \mathrm{mL}$ & $48 \mathrm{~h}$ & Increased life span & $\begin{array}{l}\text { Heat shock protein } \uparrow ; A \beta- \\
\text { induced toxicity and } \mathrm{H}_{2} \mathrm{O}_{2} \downarrow\end{array}$ & $(146)$ \\
\hline $\begin{array}{l}\text { Tian Gui Geng } \\
\text { Nian }\end{array}$ & Natural aging rat & $\begin{array}{l}0.72,1.80, \text { and } \\
4.5 \mathrm{~g} / \mathrm{kg} / \mathrm{d}\end{array}$ & 180 days & $\begin{array}{l}\text { Neuroprotection and anti- } \\
\text { aging }\end{array}$ & $\begin{array}{l}\text { ER } \beta \text {, TH positive neuron, } \\
\text { and VEGF } \uparrow \text {; G-CSF } \downarrow\end{array}$ & $(147)$ \\
\hline Zuo Gui Yin & Natural aging rat & $\begin{array}{l}13.78,20.67 \\
\text { and } 31 \mathrm{~g} / \mathrm{kg} / \mathrm{d}\end{array}$ & 8 weeks & $\begin{array}{l}\text { Promoted estradiol } \\
\text { production }\end{array}$ & $\begin{array}{l}\text { VEGF mRNA } \downarrow ; \text { SPARC } \\
\text { mRNA } \uparrow\end{array}$ & $(150)$ \\
\hline Zuo Gui Yin & Natural aging rat & $\begin{array}{l}13.78,20.67, \\
\text { and } 31.00 \mathrm{~g} / \mathrm{kg} / \\
\mathrm{d}\end{array}$ & 8 weeks & $\begin{array}{l}\text { Promoted estradiol } \\
\text { production }\end{array}$ & FSHR, LRH-1, and ER $\alpha \uparrow$ & $(151)$ \\
\hline
\end{tabular}

LWDH, Liu Wei Di Huang; RRF, a TCM Recipe Composed of Radix Astragali, Radix Angelicae Sinensis, and Folium Epimedii.

research on the anti-agining effect of CHM has developed rapidly, but no CHM has been proven to have a clinically effective anti-aging effect. In this review, CHM has been shown to have several anti-aging biological activities in vivo and in vitro, beneficial neuroprotective effects in neurodegenerative diseases like $\mathrm{AD}, \mathrm{PD}$, and skin photoaging, and cardiovascular disease protective effects.
Research has mainly focused on the components, extracts, and compounds of CHM, whose mechanisms include clinical symptom improvement, anti-oxidation, free radical scavanging, neuroendocrine level regulation, vascular endothelial function improvement, immunity and apoptosis regulation, DNA damage prevention, etc.. Among these, anti-oxidation and free radical scavenging are the most 
common. However, compared with a large number of preclinical studies, there are relatively few related clinical studies and a lack of long-term follow-up studies for endpoint events. Therefore, more convincing clinical trials are needed to confirm the efficacy of CHM, and elucidate the detailed pharmacokinetics, toxicity, standardization, and therapeutic dosage in humans. In conclusion, as a multitarget anti-aging drug, future research should pay more attention to CHM.

\section{Acknowledgments}

Funding: This work was supported by grants of National Key R\&D Program of China (2017YFC1700301), the Fundamental Research Funds for the Central public welfare research institutes (ZZ13-024-4) and Qihuang Scholar of "Millions of Talents Project" (Qihuang Project) of Traditional Chinese Medicine Inheritance and Innovation to Fengqin $\mathrm{Xu}$.

\section{Footnote}

Conflicts of Interest: All authors have completed the ICMJE uniform disclosure form (http://dx.doi.org/10.21037/ apm.2020.04.09). The authors have no conflicts of interest to declare.

Ethical Statement: The authors are accountable for all aspects of the work in ensuring that questions related to the accuracy or integrity of any part of the work are appropriately investigated and resolved.

Open Access Statement: This is an Open Access article distributed in accordance with the Creative Commons Attribution-NonCommercial-NoDerivs 4.0 International License (CC BY-NC-ND 4.0), which permits the noncommercial replication and distribution of the article with the strict proviso that no changes or edits are made and the original work is properly cited (including links to both the formal publication through the relevant DOI and the license). See: https://creativecommons.org/licenses/by-nc-nd/4.0/.

\section{References}

1. United Nations, Department of Economic and Social Affairs, Population Division. World Population Ageing 2015. (ST/ESA/SER.A/390).

2. Campisi J. Aging, Cellular Senescence, and Cancer. Annu
Rev Physiol 2013;75:685-705.

3. Christensen K, Doblhammer G, Rau R, et al. Ageing populations: the challenges ahead. Lancet 2009;374:1196-208.

4. López-Otín C, Blasco MA, Partridge L, et al. The hallmarks of aging. Cell 2013;153:1194-217.

5. Fontana L, Kennedy BK, Longo VD, et al. Medical research: treat ageing. Nature 2014;511:405-7.

6. Cava E, Fontana L. Will calorie restriction work in humans? Aging (Albany NY) 2013;5:507-14.

7. Ocampo A, Reddy P, Martinez-Redondo P, et al. In Vivo Amelioration of Age-Associated Hallmarks by Partial Reprogramming. Cell 2016;167:1719-33.e12.

8. Bitto A, Ito TK, Pineda VV, et al. Transient rapamycin treatment can increase lifespan and healthspan in middleaged mice. Elife 2016;5:e16351.

9. Mannick JB, Del GG, Lattanzi M, et al. mTOR inhibition improves immune function in the elderly. Sci Transl Med 2014;6:268ra179.

10. Onken B, Driscoll M. Metformin induces a dietary restriction-like state and the oxidative stress response to extend C. elegans Healthspan via AMPK, LKB1, and SKN-1. PLoS One 2010;5:e8758.

11. Eisenberg T, Abdellatif M, Schroeder S, et al. Cardioprotection and lifespan extension by the natural polyamine spermidine. Nat Med 2016;22:1428-38.

12. Castillo-Quan JI, Li L, Kinghorn KJ, et al. Lithium Promotes Longevity through GSK3/NRF2-Dependent Hormesis. Cell Rep 2016;15:638-50.

13. Pollack RM, Barzilai N, Anghel V, et al. Resveratrol Improves Vascular Function and Mitochondrial Number but Not Glucose Metabolism in Older Adults. J Gerontol A Biol Sci Med Sci 2017;72:1703-9.

14. Anton SD, Embry C, Marsiske M, et al. Safety and metabolic outcomes of resveratrol supplementation in older adults: results of a twelve-week, placebo-controlled pilot study. Exp Gerontol 2014;57:181-7.

15. Alway SE, McCrory JL, Kearcher K, et al. Resveratrol Enhances Exercise-Induced Cellular and Functional Adaptations of Skeletal Muscle in Older Men and Women. J Gerontol A Biol Sci Med Sci 2017;72:1595-606.

16. Witte AV, Kerti L, Margulies DS, et al. Effects of Resveratrol on Memory Performance, Hippocampal Functional Connectivity, and Glucose Metabolism in Healthy Older Adults. J Neurosci 2014;34:7862-70.

17. Wong RH, Raederstorff D, Howe P. Acute Resveratrol Consumption Improves Neurovascular Coupling Capacity in Adults with Type 2 Diabetes Mellitus. Nutrients 
2016;8:425.

18. Semba RD, Ferrucci L, Bartali B, et al. Resveratrol Levels and All-Cause Mortality in Older Community-Dwelling Adults. JAMA Intern Med 2014;174:1077.

19. Santos-Parker JR, Strahler TR, Bassett CJ, et al. Curcumin supplementation improves vascular endothelial function in healthy middle-aged and older adults by increasing nitric oxide bioavailability and reducing oxidative stress. Aging (Albany NY) 2017;9:187-208.

20. Rainey-Smith SR, Brown BM, Sohrabi HR, et al. Curcumin and cognition: a randomised, placebocontrolled, double-blind study of community-dwelling older adults. Br J Nutr 2016;115:2106-13.

21. Chiu HF, Fu HY, Lu YY, et al. Triterpenoids and polysaccharide peptides-enriched Ganoderma lucidum: a randomized, double-blind placebo-controlled crossover study of its antioxidation and hepatoprotective efficacy in healthy volunteers. Pharm Biol 2017;55:1041-6.

22. Peng XM, Gao L, Huo SX, et al. The Mechanism of Memory Enhancement of Acteoside (Verbascoside) in the Senescent Mouse Model Induced by a Combination of d-gal and AlCl3. Phytother Res 2015;29:1137-44.

23. Gao L, Peng XM, Huo SX, et al. Memory Enhancement of Acteoside (Verbascoside) in a Senescent Mice Model Induced by a Combination of d-gal and $\mathrm{AlCl} 3$. Phytother Res 2015;29:1131-6.

24. Mu X, Zhang YY, Li J, et al. Angelica Sinensis Polysaccharide Prevents Hematopoietic Stem Cells Senescence in D-Galactose-Induced Aging Mouse Model. Stem Cells Int 2017;2017:3508907.

25. Xia JY, Fan YL, Jia DY, et al. Protective effect ofAngelica sinensjs polysaccharide against liver lnjury induced by D-galactose in aging mice and its mechanisms. Zhonghua Gan Zang Bing Za Zhi 2016;24:214-9.

26. Zhang XP, Liu J, Xu CY, et al. Effect of Angelica sinensis polysaccharide on expression of telomere,telomerase and P53 in mice aging hematopoietic stem cells. Zhongguo Zhong Yao Za Zhi 2013;38:2354-8.

27. Zhang XP, Wang QX, Chen B, et al. Angelica sinensis polysaccharides delay aging of hematopoietic stem cells through inhibitting oxidative damge. Zhongguo Zhong Yao Za Zhi 2013;38:407-12.

28. Min W, Lin XF, Miao X, et al. Inhibitory effects of Baicalin on ultraviolet B-induced photo-damage in keratinocyte cell line. Am J Chin Med 2008;36:745-60.

29. Kim S, Chung JH. Berberine prevents UV-induced MMP1 and reduction of type I procollagen expression in human dermal fibroblasts. Phytomedicine 2008;15:749-53.
30. Zhu X, Yue H, Guo X, et al. The Preconditioning of Berberine Suppresses Hydrogen Peroxide-Induced Premature Senescence via Regulation of Sirtuin 1. Oxid Med Cell Longev 2017;2017:2391820.

31. Li XT, Li HC, Li CB, et al. Protective Effects on Mitochondria and Anti-Aging Activity of Polysaccharides from Cultivated Fruiting Bodies of Cordyceps militaris. Am J Chin Med 2010;38:1093-106.

32. Ma L, Chen G, Nie L, et al. Effect of Cynomorium songaricum polysaccharide on telomere length in blood and brain of D-galactose-induced senescence mice. Zhongguo Zhong Yao Za Zhi 2009;34:1257-60.

33. Shen LR, Xiao F, Yuan P, et al. Curcumin-supplemented diets increase superoxide dismutase activity and mean lifespan in Drosophila. Age (Dordr) 2013;35:1133-42.

34. Lee KS, Lee BS, Semnani S, et al. Curcumin Extends Life Span, Improves Health Span, and Modulates the Expression of Age-Associated Aging Genes in Drosophila melanogaster. Rejuvenation Res 2010;13:561-70.

35. Hou W, Gao W, Wang DT, et al. The Protecting Effect of Deoxyschisandrin and Schisandrin B on HaCaT Cells against UVB-Induced Damage. PLoS One 2015;10:e0127177.

36. Chen W, Lin HR, Wei CM, et al. Echinacoside, a phenylethanoid glycoside from Cistanche deserticola, extends lifespan of Caenorhabditis elegans and protects from A $\beta$-induced toxicity. Biogerontology 2018;19:47-65.

37. Li CP, Zhang MS, Liu J, et al. Research of anti-aging mechanism of ginsenoside Rg1 on brain. Zhongguo Zhong Yao Za Zhi 2014;39:4442-7.

38. Zeng HJ, Liu Z, Wang YP, et al. Studies on the anti-aging activity of a glycoprotein isolated from Fupenzi (Rubus chingii $\mathrm{Hu}$.) and its regulation on klotho gene expression in mice kidney. Int J Biol Macromol 2018;119:470-6.

39. Zhang SQ, Cai WJ, Huang JH, et al. Icariin, a natural flavonol glycoside, extends healthspan in mice. Exp Gerontol 2015;69:226-35.

40. Chen Y, Sun T, Wu JZ, et al. Icariin Intervenes in Cardiac Inflammaging through Upregulation of SIRT6 Enzyme Activity and Inhibition of the NF-Kappa B Pathway. BioMed Res Int 2015;2015:895976.

41. Cai WJ, Huang JH, Zhang SQ, et al. Icariin and its derivative icariside II extend healthspan via insulin/IGF-1 pathway in C. elegans. PLoS One 2011;6:e28835.

42. Xia G, Xin N, Liu W, et al. Inhibitory effect of Lycium barbarum polysaccharides on cell apoptosis and senescence is potentially mediated by the p53 signaling pathway. Mol Med Rep 2014;9:1237-41. 
43. Li JJ, Zhu Q, Lu YP, et al. Ligustilide prevents cognitive impairment and attenuates neurotoxicity in d-galactose induced aging mice brain. Brain Res 2015;1595:19-28.

44. Zheng S, Liao S, Zou Y, et al. Mulberry leaf polyphenols delay aging and regulate fat metabolism via the germline signaling pathway in Caenorhabditis elegans. Age (Dordr) 2014;36:9719.

45. Li WJ, Nie SP, Xie MY, et al. Ganoderma atrum polysaccharide attenuates oxidative stress induced by d-galactose in mouse brain. Life Sci 2011;88:713-8.

46. Li WJ, Nie SP, Peng XP, et al. Ganoderma atrum Polysaccharide Improves Age-Related Oxidative Stress and Immune Impairment in Mice. J Agric Food Chem 2012;60:1413-8.

47. Yang J, Wan QL, Mu QZ, et al. The Lifespan-Promoting Effect of Otophylloside B in Caenorhabditis elegans. Nat Prod Bioprospect 2015;5:177-83.

48. Jamal J, Mustafa MR, Wong PF. Paeonol protects against premature senescence in endothelial cells by modulating Sirtuin 1 pathway. J Ethnopharmacol 2014;154:428-36.

49. Zhang S, Cai G, Fu B, et al. SIRT1 is required for the effects of rapamycin on high glucose-inducing mesangial cells senescence. Mech Ageing Dev 2012;133:387-400

50. Shin SM, Cho IJ, Kim SG. Resveratrol protects mitochondria against oxidative stress through AMPactivated protein kinase-mediated glycogen synthase kinase-3 beta inhibition downstream of poly (ADPribose) polymerase-LKB1 pathway. Mol Pharmacol 2009;76:884-95.

51. Rajapakse AG, Yepuri G, Carvas JM, et al. Hyperactive S6K1 mediates oxidative stress and endothelial dysfunction in aging: inhibition by resveratrol. PLoS One 2011;6:e19237.

52. Mao GX, Xing WM, Wen XL, et al. Salidroside protects against premature senescence induced by ultraviolet $\mathrm{B}$ irradiation in human dermal fibroblasts. Int J Cosmet Sci 2015;37:321-8.

53. Mao GX, Deng HB, Yuan LG, et al. Protective role of salidroside against aging in a mouse model induced by D-galactose. Biomed Environ Sci 2010;23:161-6.

54. Chen P, He D, Zhang Y, et al. Sargassum fusiforme polysaccharides activate antioxidant defense by promoting Nrf2-dependent cytoprotection and ameliorate stress insult during aging. Food Funct 2016;7:4576-88.

55. Liu XY, Wang Q, Xia SJ, et al. Characteristics of lymphocyte nuclear factor- $\kappa \mathrm{B}$ signal transduction kinase expression in aging process and regulatory effect of epimedium flavonoids. Chin J Integr Med 2011;17:704-9.
56. Yan S, Wu B, Lin ZY, et al. Metabonomic characterization of aging and investigation on the anti-aging effects of total flavones of Epimedium. Mol Biosyst 2009;5:1204.

57. Wu B, Yan SK, Lin ZY, et al. Metabonomic study on ageing: NMR-based investigation into rat urinary metabolites and the effect of the total flavone of Epimedium. Mol Biosyst 2008;4:855.

58. Ning Z, Li Y, Liu D, et al. Tetrahydroxystilbene Glucoside Delayed Senile Symptoms in Old Mice via Regulation of the AMPK/SIRT1/PGC-1 $\alpha$ Signaling Cascade. Gerontology 2018;64:457-65.

59. Han CH, Lin YF, Lin YS, et al. Effects of yam tuber protein, dioscorin, on attenuating oxidative status and learning dysfunction in d-galactose-induced BALB/c mice. Food Chem Toxicol 2014;65:356-63.

60. Doan VM, Chen CX, Lin X, et al. Yulangsan polysaccharide improves redox homeostasis and immune impairment in D-galactose-induced mimetic aging. Food Funct 2015;6:1712-8.

61. Chen Y, Wei G, Nie H, et al. $\beta$-Asarone prevents autophagy and synaptic loss by reducing ROCK expression in a senescence-accelerated prone 8 mice. Brain Res 2014;1552:41-54.

62. Shin S, Son D, Kim M, et al. Ameliorating Effect of Akebia quinata Fruit Extracts on Skin Aging Induced by Advanced Glycation End Products. Nutrients 2015;7:9337-52.

63. Xiong D, Yu L, Yan X, et al. Effects of Root and Stem Extracts of Asparagus cochinchinensis on Biochemical Indicators Related to Aging in the Brain and Liver of Mice. Am J Chin Med 2011;39:719-26.

64. Liu H, Liang F, Su W, et al. Lifespan extension by n-butanol extract from seed of Platycladus orientalis in Caenorhabditis elegans. J Ethnopharmacol 2013;147:366-72.

65. Gray NE, Harris CJ, Quinn JF, et al. Centella asiatica modulates antioxidant and mitochondrial pathways and improves cognitive function in mice. J Ethnopharmacol 2016;180:78-86.

66. He M, Wu C, Ming HX, et al. Effects of Gansu Dangshen decoction on the immune function of $\mathrm{D}$-galactose induced aging mice. Xi Bao Yu Fen Zi Mian Yi Xue Za Zhi 2013;29:794-7.

67. Wang X, Wang X, Wang D, et al. Expression changes of age-related genes in different aging stages of Caenorhabiditis elegans and the regulating effects of Chuan xiong extrac. Zhongguo Zhong Yao Za Zhi 2010;35:1599-1602.

68. Yang Y, Li SS. Dandelion Extracts Protect Human Skin 
Fibroblasts from UVB Damage and Cellular Senescence. Oxid Med Cell Longev 2015;2015:619560.

69. Zhang K, Ma X, He WJ, et al. Extracts of Cistanche deserticola Can Antagonize Immunosenescence and Extend Life Span in Senescence-Accelerated Mouse Prone 8 (SAM-P8) Mice. Evid Based Complement Alternat Med 2014;2014:601383.

70. Sudheesh NP, Ajith TA, Ramnath V, et al. Therapeutic potential of Ganoderma lucidum (Fr.) P. Karst. against the declined antioxidant status in the mitochondria of postmitotic tissues of aged mice. Clin Nutr 2010;29:406-12.

71. Sudheesh NP, Ajith TA, Janardhanan KK. Ganoderma lucidum (Fr.) P. Karst enhances activities of heart mitochondrial enzymes and respiratory chain complexes in the aged rat. Biogerontology 2009;10:627-36.

72. Ajith TA, Sudheesh NP, Roshny D, et al. Effect of Ganoderma lucidum on the activities of mitochondrial dehydrogenases and complex I and II of electron transport chain in the brain of aged rats. Exp Gerontol 2009;44:219-23.

73. Bao Y, Qu Y, Li J, et al. In Vitro and In Vivo Antioxidant Activities of the Flowers and Leaves from Paeonia rockii and Identification of Their Antioxidant Constituents by UHPLC-ESI-HRMSn via Pre-Column DPPH Reaction. Molecules 2018;23:392.

74. Mao GX, Zheng LD, Cao YB, et al. Antiaging Effect of Pine Pollen in Human Diploid Fibroblasts and in a Mouse Model Induced by D-Galactose. Oxid Med Cell Longev 2012;2012:750963.

75. Yu L, Shi CX. Effect of pine pollen on kidney mitochondria DNA deletion mutation in senile mice. Zhongguo Zhong Yao Za Zhi 2012;37:1663-6.

76. Saier C, Büchter C, Koch K, et al. Polygonum multiflorum Extract Exerts Antioxidative Effects and Increases Life Span and Stress Resistance in the Model Organism Caenorhabditis elegans via DAF-16 and SIR-2.1. Plants 2018;7:60.

77. Wang P, Sun H, Liu D, et al. Protective effect of a phenolic extract containing indoline amides from Portulaca oleracea against cognitive impairment in senescent mice induced by large dose of D-galactose/NaNO2. J Ethnopharmacol 2017;203:252-9.

78. Bai L, Shi GY, Yang YJ, et al. Anti-Aging Effect of Siraitia grosuenorii by Enhancement of Hematopoietic Stem Cell Function. Am J Chin Med 2016;44:803-15.

79. Wang Y, Xu HL, Fu Q, et al. Resveratrol derived from Rhizoma Et Radix Polygoni Cuspidati and its liposomal form protect nigral cells of Parkinsonian rats. Zhongguo
Zhong Yao Za Zhi 2011;36:1060-6.

80. Park SJ, Ahmad F, Philp A, et al. Resveratrol Ameliorates Aging-Related Metabolic Phenotypes by Inhibiting cAMP Phosphodiesterases. Cell 2012;148:421-33.

81. Yu A, Dang WW. Regulation of stem cell aging by SIRT1 - Linking metabolic signaling to epigenetic modifications. Mol Cell Endocrinol 2017;455:75-82.

82. Kao CL, Chen LK, Chang YL, et al. Resveratrol protects human endothelium from $\mathrm{H}(2) \mathrm{O}(2)$-induced oxidative stress and senescence via SirT1 activation. J Atheroscler Thromb 2010;17:970-9.

83. Kim EN, Kim MY, Lim JH, et al. The protective effect of resveratrol on vascular aging by modulation of the reninangiotensin system. Atherosclerosis 2018;270:123-31.

84. Nabavi SM, Russo GL, Tedesco I, et al. Curcumin and Melanoma: From Chemistry to Medicine. Nutr Cancer 2018;70:164-75.

85. Chen Y, Liu X, Jiang CM, et al. Curcumin supplementation increases survival and lifespan in Drosophila under heat stress conditions. Biofactors 2018;44:577-87.

86. Takano K, Tatebe J, Washizawa N, et al. Curcumin Inhibits Age-Related Vascular Changes in Aged Mice Fed a High-Fat Diet. Nutrients 2018;10:1476.

87. Zhang G, Cao J, Yang E, et al. Curcumin improves agerelated and surgically induced osteoarthritis by promoting autophagy in mice. Biosci Rep 2018;38:BSR20171691.

88. Zhu J, Mu X, Zeng J, et al. Ginsenoside Rg1 prevents cognitive impairment and hippocampus senescence in a rat model of D-galactose-induced aging. PLoS One 2014;9:e101291.

89. Wang ZL, Chen LB, Qiu Z, et al. Ginsenoside Rg1 ameliorates testicular senescence changes in D-gal-induced aging mice via anti-inflammatory and antioxidative mechanisms. Mol Med Rep 2018;17:6269-76.

90. Li J, Cai DC, Yao X, et al. Protective Effect of Ginsenoside Rg1 on Hematopoietic Stem/Progenitor Cells through Attenuating Oxidative Stress and the Wnt/ $\beta$-Catenin Signaling Pathway in a Mouse Model of d-Galactoseinduced Aging. Int J Mol Sci 2016;17:849.

91. Sun J, Zhang L, Zhang J, et al. Protective effects of ginsenoside $\mathrm{Rg} 1$ on splenocytes and thymocytes in an aging rat model induced by $\mathrm{d}$-galactose. Int Immunopharmacol 2018;58:94-102.

92. Lu L, Yuan J, Zhang S. Rejuvenating activity of salidroside (SDS): dietary intake of SDS enhances the immune response of aged rats. Age (Dordr) 2013;35:637-46.

93. Jin H, Pei L, Shu XG, et al. Therapeutic Intervention of 
Learning and Memory Decays by Salidroside Stimulation of Neurogenesis in Aging. Mol Neurobiol 2016;53:851-66.

94. Sun L, Dou FF, Chen JL, et al. Salidroside slows the progression of EA.hy926 cell senescence by regulating the cell cycle in an atherosclerosis model. Mol Med Rep 2018;17:257-63.

95. Chinese Pharmacopoeia Commission. Pharmacopoeia of the People's Republic of China. Chinese Medical Science Press, Beijing, China, 2010;228.

96. Zhao H, Song L, Huang W, et al. Total flavonoids of Epimedium reduce ageing-related oxidative DNA damage in testis of rats via p53-dependent pathway. Andrologia 2017;49:e12756.

97. Wu B, Chen Y, Huang JH, et al. Icariin improves cognitive deficits and activates quiescent neural stem cells in aging rats. J Ethnopharmacol 2012;142:746-53.

98. Wang GQ, Li DD, Huang C, et al. Icariin Reduces Dopaminergic Neuronal Loss and Microglia-Mediated Inflammation in Vivo and in Vitro. Front Mol Neurosci 2018; 10:441

99. Xiao H, Xiong L, Song X, et al. Angelica sinensis Polysaccharides Ameliorate Stress-Induced Premature Senescence of Hematopoietic Cell via Protecting Bone Marrow Stromal Cells from Oxidative Injuries Caused by 5-Fluorouracil. Int J Mol Sci 2017;18:2265.

100. Yang F, Yan GG, Li Y, et al. Astragalus Polysaccharide Attenuated Iron Overload-Induced Dysfunction of Mesenchymal Stem Cells via Suppressing Mitochondrial ROS. Cell Physiol Biochem 2016;39:1369-79.

101. Wang X, Zhang JL, Lu LL, et al. The longevity effect of echinacoside in Caenorhabditis elegans mediated through daf-16. Biosci Biotechnol Biochem 2015;79:1676-83.

102.Lee SY, Ahn SM, Wang ZY, et al. Neuroprotective effects of 2,3,5,4'-tetrahydoxystilbene-2-O- $\beta$-D-glucoside from Polygonum multiflorum against glutamate-induced oxidative toxicity in HT22 cells. J Ethnopharmacol 2017;195:64-70.

103. Chen T, Yang YJ, Li YK, et al. Chronic administration tetrahydroxystilbene glucoside promotes hippocampal memory and synaptic plasticity and activates ERKs, CaMKII and SIRT1/miR-134 in vivo. J Ethnopharmacol 2016;190:74-82.

104. Ahn SM, Kim HN, Kim YR, et al. Emodin from Polygonum multiflorum ameliorates oxidative toxicity in HT22 cells and deficits in photothrombotic ischemia. J Ethnopharmacol 2016;188:13-20.

105. Yang JB, Li WF, Liu Y, et al. Acute toxicity screening of different extractions, components and constituents of
Polygonum multiflorum Thunb. on zebrafish (Danio rerio) embryos in vivo. Biomed Pharmacother 2018;99:205-13.

106. Gurovic MSV, Viceconte FR, Pereyra MT, et al. DNA damaging potential of Ganoderma lucidum extracts. J Ethnopharmacol 2018;217:83-8.

107.Levin RM, Xia L, Wei W, et al. Effects of Ganoderma Lucidum shell-broken spore on oxidative stress of the rabbit urinary bladder using an in vivo model of ischemia/ reperfusion. Mol Cell Biochem 2017;435:25-35.

108. Stefanova NA, Fursova A, Sarsenbaev KN, et al. Effects of Cistanche deserticola on behavior and signs of cataract and retinopathy in senescence-accelerated OXYS rats. J Ethnopharmacol 2011;138:624-32.

109. Lin WY, Yao C, Cheng J, et al. Molecular pathways related to the longevity promotion and cognitive improvement of Cistanche tubulosa in Drosophila. Phytomedicine 2017;26:37-44.

110.Liu HP, Chang RF, Wu YS, et al. The Yang-Tonifying Herbal Medicine Cynomorium songaricum Extends Lifespan and Delays Aging in Drosophila. Evid Based Complement Alternat Med 2012;2012:735481.

111.Lu Y, Wang QG, Melzig MF, et al. Extracts of Cynomorium songaricum protect SK-N-SH human neuroblastoma cells against staurosporine-induced apoptosis potentially through their radical scavenging activity. Phytother Res 2009;23:257-61.

112. Yu FR, Liu Y, Cui YZ, et al. Effects of a flavonoid extract from Cynomorium songaricum on the swimming endurance of rats. Am J Chin Med 2010;38:65-73.

113. Chang YM, Chang HH, Kuo WW, et al. Anti-Apoptotic and Pro-Survival Effect of Alpinate Oxyphyllae Fructus (AOF) in a d-Galactose-Induced Aging Heart. Int J Mol Sci 2016;17:466.

114. Chang YM, Chang HH, Lin HJ, et al. Inhibition of Cardiac Hypertrophy Effects in D-Galactose-Induced Senescent Hearts by Alpinate Oxyphyllae Fructus Treatment. Evid Based Complement Alternat Med 2017;2017:2624384.

115. Wan F, Zhi D, Liu D, et al. Lifespan extension in Caenorhabiditis elegans by several traditional Chinese medicine formulas. Biogerontology 2014;15:377-87.

116.Zhang GR, Cheng XR, Zhou WX, et al. Age-related expression of STUB1 in senescence-accelerated mice and its response to anti-Alzheimer's disease traditional Chinese medicine. Neurosci Lett 2008;438:371-5.

117.Zhang GR, Cheng XR, Zhou WX, et al. Age-related expression of calcium/calmodulin-dependent protein kinase II A in the hippocampus and cerebral cortex of 
senescence accelerated mouse prone $/ 8$ mice is modulated by anti-Alzheimer's disease drugs. Neuroscience 2009;159:308-15.

118. Yang Y, Cheng XR, Zhang GR, et al. Autocrine motility factor receptor is involved in the process of learning and memory in the central nervous system. Behav Brain Res 2012;229:412-8.

119.Huang Y, Zhang HP, Yang S, et al. Liuwei Dihuang decoction facilitates the induction of long-term potentiation (LTP) in senescence accelerated mouse/prone 8 (SAMP8) hippocampal slices by inhibiting voltagedependent calcium channels (VDCCs) and promoting $\mathrm{N}$-methyl-d-aspartate receptor (NMDA) receptors. J Ethnopharmacol 2012;140:384-90.

120.Wang J, Liu Y, Cheng X, et al. The Effects of LW-AFC on the Hippocampal Transcriptome in SenescenceAccelerated Mouse Prone 8 Strain, a Mouse Model of Alzheimer's Disease. J Alzheimers Dis 2017;57:227-40.

121. Tseng YT, Chang FR, Lo YC. The Chinese herbal formula Liuwei dihuang protects dopaminergic neurons against Parkinson's toxin through enhancing antioxidative defense and preventing apoptotic death. Phytomedicine 2014;21:724-33.

122. Hu ZY, Liu G, Yuan H, et al. Danggui-Shaoyao-San and its active fraction JD-30 improve $\mathrm{A} \beta$-induced spatial recognition deficits in mice. Journal of Ethnopharmacology 2010;128:365-72.

123. Huang Y, Hu ZY, Yuan H, et al. Danggui-Shaoyao-San Improves Learning and Memory in Female SAMP8 via Modulation of Estradiol. Evid Based Complement Alternat Med 2014;2014:327294.

124.Luo Y, Wang Q, Zhang YB. A systems pharmacology approach to decipher the mechanism of danggui-shaoyaosan decoction for the treatment of neurodegenerative diseases. J Ethnopharmacol 2016;178:66-81.

125. Ren C, Wang B, Li N, et al. Herbal Formula DangguiShaoyao-San Promotes Neurogenesis and Angiogenesis in Rat Following Middle Cerebral Artery Occlusion. Aging Dis 2015;6:245.

126. Lai N, Zhang Z, Wang B, et al. Regulatory effect of Traditional Chinese Medicinal Formula Zuo-GuiWan on the Th17/Treg paradigm in mice with bone loss induced by estrogen deficiency. J Ethnopharmacol 2015;166:228-39.

127.Kou S, Zheng Q, Wang YZ, et al. Zuo-Gui and YouGui pills, two traditional Chinese herbal formulas, downregulated the expression of NogoA, NgR, and RhoA in rats with experimental autoimmune encephalomyelitis. J
Ethnopharmacol 2014;158:102-12.

128. Mo Y, Xu E, Wei R, et al. Bushen-Yizhi Formula Alleviates Neuroinflammation via Inhibiting NLRP3 Inflammasome Activation in a Mouse Model of Parkinson's Disease. Evid Based Complement Alternat Med 2018;2018:3571604.

129.Zhang SJ, Luo D, Li L, et al. Ethyl Acetate Extract Components of Bushen-Yizhi Formula Provides Neuroprotection against Scopolamine-induced Cognitive Impairment. Sci Rep 2017;7:9824.

130. Cai H, Luo Y, Yan X, et al. The Mechanisms of BushenYizhi Formula as a Therapeutic Agent against Alzheimer's Disease. Sci Rep 2018;8:3104.

131.Hou XQ, Wu DW, Zhang CX, et al. BushenYizhi formula ameliorates cognition deficits and attenuates oxidative stressrelated neuronal apoptosis in scopolamineinduced senescence in mice. Int J Mol Med 2014;34:429-39.

132.Zhang SJ, Xu TT, Li L, et al. Bushen-Yizhi formula ameliorates cognitive dysfunction through SIRT1/ ER stress pathway in SAMP8 mice. Oncotarget 2017;8:49338-50.

133.Hou XQ, Song HP, Chen YB, et al. Effects of BushenYizhi formula on age-related inflammation and oxidative stress in senescence-accelerated mice. Mol Med Rep 2018;17:6947-60.

134. Qu Z, Yang HG, Zhang JZ, et al. Cerebralcare Granule®, a Chinese Herb Compound Preparation, Attenuates d-Galactose Induced Memory Impairment in Mice. Neurochem Res 2016;41:2199-214.

135.Lan Z, Liu JP, Chen LY, et al. Danggui-Shaoyao-San ameliorates cognition deficits and attenuates oxidative stress-related neuronal apoptosis in d-galactose-induced senescent mice. J Ethnopharmacol 2012;141:386-95.

136.Hu ZY, Liu G, Cheng XR, et al. JD-30, an active fraction extracted from Danggui-Shaoyao-San, decreases $\beta$-amyloid content and deposition, improves LTP reduction and prevents spatial cognition impairment in SAMP8 mice. Exp Gerontol 2012;47:14-22.

137.Zhang ZX, Zhao RP, Wang DS, et al. Fuzhisan Ameliorates the Memory Deficits in Aged SAMP8 Mice via Decreasing A $\beta$ Production and Tau Hyperphosphorylation of the Hippocampus. Neurochem Res 2016;41:3074-82.

138. Meng F, Li J, Wang WJ, et al. Gengnianchun, a Traditional Chinese Medicine, Enhances Oxidative Stress Resistance and Lifespan inCaenorhabditis elegans by Modulating daf-16/FOXO. Evid Based Complement Alternat Med 2017;2017:8432306.

139. Chen J, Wang Y, Hui C, et al. Mechanisms of Heshouwuyin in regulating apoptosis of testicular cells 
in aging rats through mitochondrial pathway. BMC

Complement Altern Med 2016;16:337.

140.Zheng Y, Cheng XR, Zhou WX, et al. Gene expression patterns of hippocampus and cerebral cortex of senescence-accelerated mouse treated with Huang-LianJie-Du decoction. Neurosci Lett 2008;439:119-24.

141.Zhang J, Fang L, Shi L, et al. Protective effects and mechanisms investigation of Kuntai capsule on the ovarian function of a novel model with accelerated aging ovaries. J Ethnopharmacol 2017;195:173-81.

142. Sangha JS, Sun X, Wally OS, et al. Liuwei Dihuang (LWDH), a traditional Chinese medicinal formula, protects against beta-amyloid toxicity in transgenic Caenorhabditis elegans. PLoS One 2012;7:e43990.

143.Wang J, Cheng X, Zeng J, et al. LW-AFC Effects on $\mathrm{N}$-glycan Profile in Senescence-Accelerated Mouse Prone 8 Strain, a Mouse Model of Alzheimer's Disease. Aging Dis 2017;8:101.

144.Wang J, Ye F, Cheng X, et al. The Effects of LW-AFC on Intestinal Microbiome in Senescence-Accelerated Mouse Prone 8 Strain, a Mouse Model of Alzheimer's Disease. J Alzheimers Dis 2016;53:907-19.

145.Su JY, Xie QF, Liu WJ, et al. Perimenopause Amelioration of a TCM Recipe Composed of Radix Astragali, Radix Angelicae Sinensis, and Folium Epimedii: AnIn Vivo Study on Natural Aging Rat Model. Evid Based Complement

Cite this article as: Zhao J, Lan X, Liu Y, Liu Y, Xian Y, Lin Z, $\mathrm{Xu}$ F. Anti-aging role of Chinese herbel medicine: an overview of scientific evidence from 2008 to 2018. Ann Palliat Med 2020;9(3):1230-1248. doi: 10.21037/apm.2020.04.09
Alternat Med 2013;2013:747240.

146. Yu YB, Dosanjh L, Lao L, et al. Cinnamomum cassia bark in two herbal formulas increases life span in Caenorhabditis elegans via insulin signaling and stress response pathways. PLoS One 2010;5:e9339.

147.Li YJ, Song TB, Zhao X, et al. The Protective Roles of Tian gui Geng nian Soft Capsule on Brain in Aged Female Rats and its Mechanism. Zhongguo Zhong Xi Yi Jie He Za Zhi 2009;29:619-22.

148. Xu LW, Kluwe L, Zhang TT, et al. Chinese herb mix Tiáo-Gēng-Tāng possesses antiaging and antioxidative effects and upregulates expression of estrogen receptors alpha and beta in ovariectomized rats. BMC Complement Altern Med 2011;11:137.

149.Liang L, Zhang XH, Ji B, et al. Yifuning postpones ovarian aging through antioxidant mechanisms and suppression of the $\mathrm{Rb} / \mathrm{p} 53$ signal transduction pathway. Mol Med Rep 2016;14:888-96.

150.Zhao W, Wen HX, Zheng HL, et al. Effect of Zuoguiyin on expression of ovarian VEGF and SPARC in rats during peri-menopausal period. Zhongguo Zhong Yao Za Zhi 2009;34:2932-6.

151.Zhao W, Wen HX, Zheng HL, et al. Action mechanism of Zuo Gui Yin Decoction's promotion on estradiol production in rats during the peri-menopausal period. J Ethnopharmacol 2011;134:122-9. 